\title{
Effects of indirect indicators of udder health on nutrient recovery and cheese yield traits in goat milk
}

\author{
Giorgia Stocco, ${ }^{1}$ Michele Pazzola, ${ }^{1 *}$ Maria L. Dettori, ${ }^{1}$ Pietro Paschino, ${ }^{1}$ Andrea Summer, ${ }^{2}$ \\ Claudio Cipolat-Gotet, ${ }^{2}$ and Giuseppe M. Vacca ${ }^{1}$ \\ ${ }^{1}$ Department of Veterinary Medicine, University of Sassari, 07100 Sassari, Italy \\ ${ }^{2}$ Department of Veterinary Science, University of Parma, 43126 Parma, Italy
}

\begin{abstract}
In dairy goats, very little is known about the effect of the 2 most important indirect indicators of udder health [somatic cell count (SCC) and total bacterial count (TBC)] on milk composition and cheese yield, and no information is available regarding the effects of lactose levels, $\mathrm{pH}$, and $\mathrm{NaCl}$ content on the recovery of nutrients in the curd, cheese yield traits, and daily cheese yields. Because large differences exist among dairy species, conclusions from the most studied species (i.e., bovine) cannot be drawn for all types of dairy-producing animals. The aims of this study were to quantify, using milk samples from 560 dairy goats, the contemporary effects of a pool of udder health indirect indicators (lactose level, $\mathrm{pH}, \mathrm{SCC}, \mathrm{TBC}$, and $\mathrm{NaCl}$ content) on the recovery of nutrients in the curd (\%REC), cheese yield (\%CY), and daily cheese yields $(\mathrm{dCY})$. Cheese-making traits were analyzed using a mixed model, with parity, days in milk (DIM), lactose level, $\mathrm{pH}, \mathrm{SCC}, \mathrm{TBC}$, and $\mathrm{NaCl}$ content as fixed effects, and farm, breed, glass tube, and animal as random effects. Results indicated that high levels of milk lactose were associated with reduced total solids recovery in the curd and lower cheese yields, because of the lower milk fat and protein contents in samples rich in lactose. Higher $\mathrm{pH}$ correlated with higher recovery of nutrients in the curd and higher cheese yield traits. These results may be explained by the positive correlation between $\mathrm{pH}$ and milk fat, protein, and casein in goat milk. High SCC were associated with higher recovery of solids and energy in the curd but lower recovery of protein. The higher cheese yield obtained from milk with high SCC was due to both increased recovery of lactose in the curd and water retention. Bacterial count proved to be the least important factor affecting cheese-making traits, but it decreased daily cheese yields, suggesting
\end{abstract}

Received January 25, 2019.

Accepted May 28, 2019.

*Corresponding author: pazzola@uniss.it that, even if below the legal limits, TBC should be considered in order to monitor flock management and avoid economic losses. The effect of $\mathrm{NaCl}$ content on milk composition was linked with lower recovery of all nutrients in the curd during cheese-making. In addition, high milk $\mathrm{NaCl}$ content led to reductions in fresh cheese yield and cheese solids. The indirect indicators of the present study significantly affected the cheese-making process. Such information should be considered, to adjust the milk-to-cheese economic value and the milk payment system.

Key words: lactose, somatic cells, bacterial count, cheese-making, $\mathrm{NaCl}$

\section{INTRODUCTION}

Goat milk is mostly used for cheese-making, and among its components, fat and protein highly influence yield and traits of cheese (Guo et al., 2004; Stocco et al., 2018; Pazzola et al., 2019). In cattle, besides fat and protein, milk traits such as lactose levels, $\mathrm{pH}, \mathrm{NaCl}$ content, SCC, and total bacterial count (TBC) are unequivocally associated with the udder health status of dairy cows (Charjan-Ku et al., 2000; Pyörälä, 2003), and are also linked to a deterioration of the cheesemaking process. High SCC and TBC in cow milk are associated with a high $\mathrm{pH}$, with markedly worsened protein quality, decreased fat and lactose contents (Ogola et al., 2007), and reduced cheese yield (\%CY; Summer et al., 2015). However, very little is known about the effects of these indirect indicators of udder health on cheese-making from goat milk, and results in the literature about estimation of udder health status of goats using SCC and TBC, and their effects on milk composition, are sometimes controversial (Stuhr and Aulrich, 2010).

In dairy goats, clear relationships between the most common indirect indicators of udder health status (i.e., SCC and TBC) and worsening of milk quality have not been evidenced. Gelasakis et al. (2018) have recently shown that milk from goats with subclinical mastitis 
is characterized by lower fat and lactose contents and slightly higher protein content compared with healthy goats. However, SCC and TBC are the traits that can most easily and inexpensively give information on mammary gland health status, in dairy cows and also in dairy goats (Rupp et al., 2009). Besides SCC and TBC, other milk constituents have been proposed as indirect indicators of udder health. The negative relationship between lactose and SCC has also been demonstrated in goats. Indeed, in goats without any symptoms of clinical mastitis, lactose affects the coagulation ability of milk, with high levels of lactose associated with reduced coagulation time and weakened curd firmness traits (Stocco et al., 2019). In dairy cows, during udder inflammation (Batavani et al., 2007), an increase of milk $\mathrm{pH}$ and a consequent deterioration of milk coagulation (i.e., gelation and curd-firming) are expected (Fox et al., 2017), but the effect of goat milk $\mathrm{pH}$ on cheese-making traits is not well documented. Again, in dairy cows, the concentration of milk $\mathrm{NaCl}$ increases in cases of mastitis, with an adverse effect on the concentration of other milk constituents (Batavani et al., 2007). In goat milk, high levels of $\mathrm{NaCl}$ (i.e., higher than $319 \mathrm{mg} / 100 \mathrm{~mL}$; Stocco et al., 2019) are associated with reduced fat, protein, and casein contents, as well as with worsened coagulation ability.

Large differences exist among species, and the contemporary effects of lactose levels, pH, SCC, TBC, and $\mathrm{NaCl}$ content on the recovery of nutrients in the curd, cheese yield traits, and daily cheese yields of goat milk have not yet been investigated. The aims of this study were to quantify the effects of a pool of indirect udder health indicators from individual goat milk (lactose level, $\mathrm{pH}, \mathrm{SCC}, \mathrm{TBC}$, and $\mathrm{NaCl}$ content) on (1) selected milk nutrient recovery traits in the curd (\%REC) — fat, protein, total solids, and energy; (2) selected cheese yield traits $(\% \mathrm{CY})$ - fresh curd, curd dry matter, and water retained in curd; and (3) daily cheese yields (dCY), obtained by multiplying each \%CY trait by the daily milk yield of goats.

\section{MATERIALS AND METHODS}

\section{Milk Sampling and Udder Health Indicator Analysis}

Milk samples were collected from 560 goats belonging to 6 different breeds (Saanen, Camosciata delle Alpi, Murciano-Granadina, Maltese, Sarda, and Sarda Primitiva) and reared in 35 farms distributed over the whole island of Sardinia, Italy. Study animals were selected from those officially registered in the flock books and enrolled in the milk recording system of provincial associations of goat breeders. Goats were milk-sampled once (single-day sampling at each farm) during afternoon milking. Details of farm characteristics and description of the breeds have been previously reported by Vacca et al. (2018a). Briefly, type of management on farms ranged from traditional (extensive goat dairy system with free grazing of natural pastures, seasonal milk production, family operated) to modern (semi-intensive system, housing in modern buildings and use of modern facilities, common use of TMR, out-of-season kidding and continuous milk production, operated by hired workers, consultancy of experts in animal feeding). Flock size ranged from small (fewer than 100 producing goats) to large (more than 200). Saanen goats $(\mathrm{n}=$ 99) were characterized by means \pm standard deviation (SD) of parity at $3.3 \pm 1.7$ and DIM at $109 \pm 72$; Camosciata delle Alpi goats $(\mathrm{n}=98)$ had parity and DIM very close to the Saanen breed $(3.1 \pm 2.0$ and 78 \pm 37 , respectively). Parity and DIM of the MurcianoGranadina goats $(\mathrm{n}=89)$ were similar to those of the 2 dairy breeds of Alpine origin (Saanen and Camosciata delle Alpi), with parity at $3.0 \pm 1.4$ and DIM at 129 \pm 38 . Maltese goats $(\mathrm{n}=104)$ had parity at $3.8 \pm 1.7$ and DIM at $129 \pm 49$. The Sarda and Sarda Primitiva are local breeds from the island of Sardinia, classified as Mediterranean types, as are the Murciano-Granadina breed. Sarda goats $(\mathrm{n}=86)$ in this study had parity at $4.7 \pm 2.0$ and DIM at $129 \pm 36$, and Sarda Primitiva $(\mathrm{n}=84)$ were characterized by parity at $5.1 \pm 2.5$ and DIM at $124 \pm 40$.

Milk fat, protein, total solids, and lactose levels (expressed as \%), pH, and $\mathrm{NaCl}$ content (expressed as $\mathrm{mg} / 100 \mathrm{~mL}$ ) were determined using a MilkoScan FT6000 milk analyzer (Foss Electric A/S, Hillerød, Denmark), calibrated according to FIL-IDF references (ISO-IDF, 2010, 2013); SCC and TBC were measured using a Fossomatic 5000 somatic cell counter and a BactoScan FC150 analyzer (both from Foss Electric A/S), respectively. These traits were then transformed into the logarithmic somatic cell score $\left[\mathrm{SCS}=\log _{2}(\mathrm{SCC}\right.$ $\left.\left.\times 10^{-5}\right)+3\right]$ and logarithmic bacterial count $[\mathbf{L B C}=$ $\left.\log _{10}(\mathrm{TBC} / 1,000)\right]$, respectively.

\section{Cheese-Making Traits}

To measure cheese-making traits, we used the 9-mL milk cheese-making assessment (9-MilCA) method proposed by Cipolat-Gotet et al. (2016). The following procedure was performed in duplicate for each goat milk sample (2 replicates of $9 \mathrm{~mL}$ from the same milk sample), for a total of 1,120 observations. Each replicate $(9 \mathrm{~mL})$ was poured into a glass tube, inserted into the sample rack of the lactodynamograph instrument (Formagraph, Foss Italia S.P.A., Padova, Italy), heated to $35^{\circ} \mathrm{C}$ for $15 \mathrm{~min}$, and mixed with $0.2 \mathrm{~mL}$ of a rennet solution [Hansen Standard 215, with $80 \pm 5 \%$ chymosin 
and $20 \pm 5 \%$ pepsin, 215 international milk clotting units (IMCU)/mL (Pacovis Amrein AG, Bern, Switzerland), diluted to $1.2 \%$ (wt/vol) in distilled water]. The sample rack was then transferred to the lactodynamograph for curd firmness measurements $\left(30 \mathrm{~min}\right.$ at $\left.35^{\circ} \mathrm{C}\right)$. At the end of curd firmness analysis, coagulated milk replicates were manually cut and moved to the heater for the curd-cooking phase $\left(30 \mathrm{~min}\right.$ at $\left.55^{\circ} \mathrm{C}\right)$. In the middle of the cooking phase, each replicate was subjected to a further manual cutting by the same operator. Then each glass tube was removed from the sample rack, and the curd was separated from the whey. The curd was manually pressed with a stainless-steel spatula and suspended above the whey for $15 \mathrm{~min}$ at room temperature for draining. The obtained curd and whey were weighed using a precision scale. An infrared spectrophotometer (Foss Electric A/S) was used to analyze whey composition (fat, protein, lactose, and total solids). The weights of the milk, curd, and whey (in g), and the chemical composition of milk and whey allowed us to estimate curd composition by calculating the difference between milk and whey. The nutrient recovery traits for protein, fat, and solids were $\mathbf{\% R E C}_{\text {PROTEIN }}, \mathbf{F R E C}_{\mathrm{FAT}}$, and \% $\mathbf{R E C}_{\text {SOLIDS }}$, calculated as the ratio of the weight of the curd components (protein, fat, and total solids, respectively) to the weight of the same milk component, and multiplied by 100 . Recovery of energy in the curd $\left(\%\right.$ REC $\left._{\text {ENERGY }}\right)$ was calculated by estimating energy of milk and curd using an equation proposed by the NRC (2001), converted to $\mathrm{MJ} / \mathrm{kg}$ and multiplied by 100. The cheese yield traits (\%CY) for curd, solids, and water were $\mathbf{C C Y}_{\mathbf{C U}}, \mathbf{\%} \mathbf{C Y}_{\text {SOLIDS }}$, and $\mathbf{\% C Y}_{\text {WATER }}$, calculated as the ratio of the weight of fresh curd, curd dry matter, and water retained in curd, respectively, to the weight of the milk processed, and multiplied by 100 . Daily cheese yields of curd, solids, and water $\left(\mathbf{d C Y}_{\mathbf{C U R D}}, \mathbf{d C Y}_{\text {SOLIDS }}\right.$, and $\left.\mathbf{d C} \mathbf{Y}_{\text {WATER }} ; \mathrm{kg} / \mathrm{d}\right)$ were calculated by multiplying \%CY (\% $\mathrm{CY}_{\mathrm{CURD}}, \% \mathrm{CY}$ SOLIDS, and $\% \mathrm{CY}_{\text {WATER }}$, respectively) by the individual daily milk yield of goats. Daily milk yield of goats (dMY, $\mathrm{kg} / \mathrm{d}$ ) was calculated as the total yield of morning plus afternoon milking of the same day of milk sampling.

\section{Statistical Analysis}

Cheese-making traits (\%REC, \%CY, and dCY) were analyzed using a MIXED procedure (SAS Institute Inc., Cary, NC), according to the following model:

$$
\begin{aligned}
& \mathrm{Y}_{\text {efghijklmnop }}=\mu+\text { DIM }_{\mathrm{e}}+\text { Parity }_{\mathrm{f}}+\text { Lactose }_{\mathrm{g}}+\mathrm{pH}_{\mathrm{h}} \\
& +\mathrm{SCS}_{\mathrm{i}}+\mathrm{LBC}_{\mathrm{j}}+\mathrm{NaCl}_{\mathrm{k}}+\text { Farm }_{\mathrm{l}}+\text { Breed }_{\mathrm{m}} \\
& + \text { Glass } \text { Tube }_{n}+\text { Animal }_{o}+\text { e efghijklmnop }
\end{aligned}
$$

where $Y_{\text {efghijklmnop }}$ is the observed trait; $\mu$ is the overall intercept of the model; $\mathrm{DIM}_{\mathrm{e}}$ is the fixed effect of the eth class of days in milk $[\mathrm{e}=1$ to 4 ; class $1: \leq 80 \mathrm{~d}$ (146 goats); class 2: 81-120 d (157 goats); class 3: 121-160 d (157 goats); class 4: > $160 \mathrm{~d}$ (100 goats)]; Parity is the $_{\mathrm{f}}$ fixed effect of the fth parity [ $\mathrm{f}=1$ to 3 ; class 1 : 1 st and 2nd (193 goats); class 2: 3rd and 4th (205 goats); class $3: \geq 5$ th (162 goats)]; Lactose $_{g}$ is the fixed effect of the gth class of lactose content $(\mathrm{g}=1$ to 7 ; class 1 : < $4.32 \%$; class 2 : $4.32-4.45 \%$; class $3: 4.46-4.58 \%$; class 4 : 4.59-4.73\%; class 5: 4.74-4.86\%; class 6: $4.87-4.99 \%$; class $7:>4.99 \%) ; \mathrm{pH}_{\mathrm{h}}$ is the fixed effect of the hth class of $\mathrm{pH}(\mathrm{h}=1$ to 7 ; class $1:<6.59$; class $2: 6.59-6.63$; class 3: 6.64-6.69; class 4: 6.70-6.75; class 5: 6.76-6.80; class 6: 6.81-6.85; class 7: $>6.85)$; $\mathrm{SCS}_{\mathrm{i}}$ is the fixed effect of the ith class of SCS ( $\mathrm{i}=1$ to 7 ; class $1:<3.15$; class 2: $3.15-4.12$; class 3 : $4.13-5.11$; class 4 : $5.12-6.11$; class 5: 6.12-7.10; class 6: 7.11-8.08; class 7: > 8.08); $\mathrm{LBC}_{\mathrm{j}}$ is the fixed effect of the jth class of $\mathrm{LBC}(\mathrm{j}=1$ to 7; class 1: < 0.76; class 2: $0.76-1.16$; class $3: 1.17-1.58$; class 4: 1.59-2.01; class 5: 2.02-2.43; class 6: 2.44-2.83; class $7:>2.83) ; \mathrm{NaCl}_{\mathrm{k}}$ is the fixed effect of the kth class of $\mathrm{NaCl}(\mathrm{k}=1$ to 7 ; class $1:<184 \mathrm{mg} / 100 \mathrm{~mL}$; class 2 : 184-209 mg/100 mL; class 3: 210-235 mg/100 mL; class 4: $236-262 \mathrm{mg} / 100 \mathrm{~mL}$; class 5: $263-288 \mathrm{mg} / 100$ $\mathrm{mL}$; class 6: 289-315 mg/100 mL; class 7: > $315 \mathrm{mg} / 100$ $\mathrm{mL}) ; \mathrm{Farm}_{1}$ is the random effect of the lth farm $(1=1$ to 35); Breed $_{\mathrm{m}}$ is the random effect of the mth breed ( $\mathrm{m}$ = Saanen, Camosciata delle Alpi, Murciano-Granadina, Maltese, Sarda, or Sarda Primitiva); Glass Tube ${ }_{n}$ is the random effect of the nth glass tube of the lactodynamograph instrument ( $\mathrm{n}=1$ to 8); Animal $_{\mathrm{o}}$ is the random effect of the oth animal ( $\mathrm{o}=1$ to 560 ); $\mathrm{e}_{\text {efghijklmnop }}$ is the random residual $\sim N\left(0, \sigma_{e}^{2}\right)$, where $\sigma_{e}^{2}$ is the residual variance. The 7 classes for lactose, $\mathrm{pH}, \mathrm{SCS}, \mathrm{LBC}$, and $\mathrm{NaCl}$ were designed on the basis of distribution of the variables: each single class explained $0.5 \mathrm{SD}$ of the variable; the fourth class was centered on the mean value; and the first and the seventh classes represented the tails of the distribution.

Orthogonal polynomial contrasts (linear, quadratic, and cubic pattern) were estimated between least squares means (LSM) of milk indirect indicators (lactose level, $\mathrm{pH}, \mathrm{SCS}, \mathrm{LBC}$, and $\mathrm{NaCl}$ concentration) of udder health.

\section{RESULTS AND DISCUSSION}

Mean and SD of cheese-making traits (\%REC, \%CY, and $\mathrm{dCY}$ ), fixed effects (DIM, parity), and random effects (farm, breed, animal, glass tube of the instrument) are summarized in Table 1. Their effects on cheese-making traits, using the same data set as the 


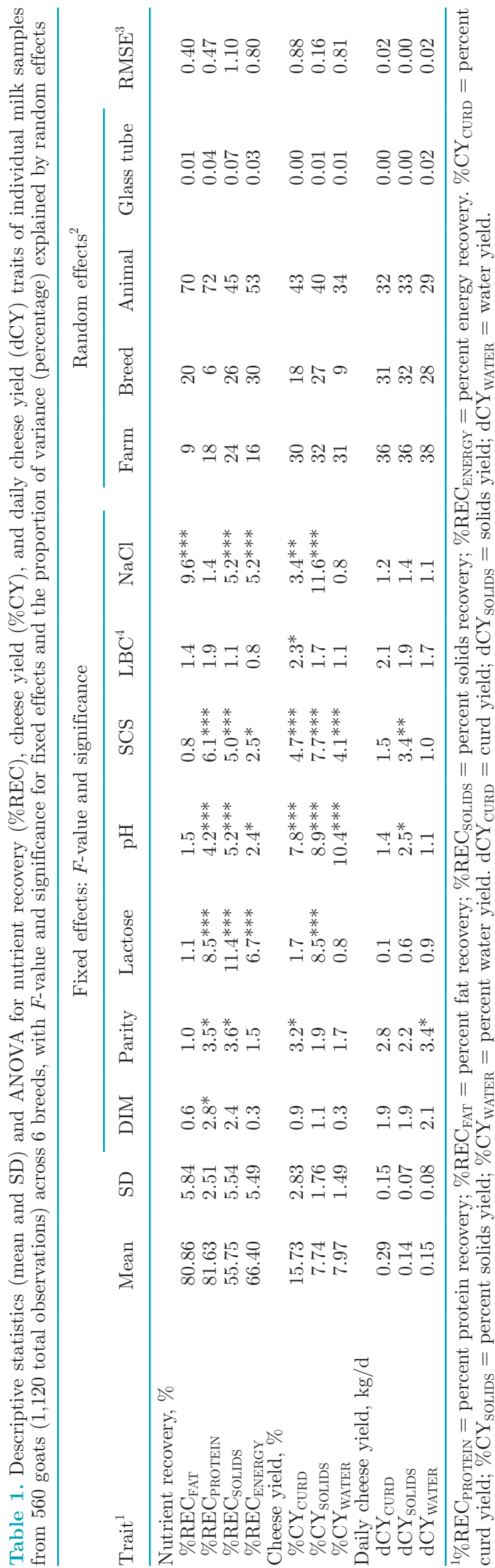

present study, are reported and discussed in a previous study (Vacca et al., 2018b).

\section{Effects of Lactose}

In goats, a few studies have focused on the relationship between SCC and lactose (Pirisi et al., 2000; Albenzio et al., 2004), but no information is reported about the effects of lactose on cheese-making. The effects of different concentrations of milk lactose on coagulation, curd-firming, and syneresis from 1,272 individual goat samples has been reported by Stocco et al. (2019). In that study, high levels of lactose were associated with decreases in milk fat, protein, and casein contents, worsened curd-firming rate, and weakened curd firmness traits. Moreover, as a consequence of the negative relationship between lactose and milk composition (fat and casein), decreased values of \%REC $\mathrm{CRROTEIN}_{\text {and }}$ $\% \mathrm{REC}_{\text {SOLIDS }}$ were recorded for samples with high lactose content (Pazzola et al., 2019). Those findings, together with the negative association between lactose and curd firmness, could explain also the lower $\% \mathrm{CY}_{\text {SOLIDS }}$ for goats with higher milk lactose $(P<0.001$, Table 2$)$. Because of these associations, and due to the fact that lactose is almost completely lost in the whey during cheese-making, \% REC $_{\text {ENERGY }}$ was also lower in curds made from lactose-rich milk samples. As for the other indirect heath traits, the effects of milk lactose were tested, including DIM and parity in the model. For this reason, the aforementioned results cannot be related to the variability of DIM and parity among the goats.

\section{Effects of $\mathrm{pH}$}

Milk $\mathrm{pH}$ is one of the most important traits influencing composition and coagulation properties (Calvo and Balcones, 2000). During cheese-making, when cow milk is acidified, gelation time decreases and curd firmness markedly increases (Stocco et al., 2015). Goat milk samples with increased $\mathrm{pH}$ values are associated with a worsening of coagulation abilities (i.e., longer coagulation time, weaker curd firmness) and with an enhancement of curd-firming and syneresis (Stocco et al., 2019). However, the results obtained for the effects of milk $\mathrm{pH}$ on coagulation were not completely associable to what we found for cheese-making traits. When compared with milk with lower $\mathrm{pH}$, samples with high $\mathrm{pH}$ showed greater recovery of milk nutrients in the curd, especially \% $\mathrm{REC}_{\text {PROTEIN }}$ and $\% \mathrm{REC}_{\text {SOLIDS }}$ $(P<0.001$, Table 3). Greater \%REC also produced higher values of \%CY traits, as reported in Table 3. The positive relationships between milk $\mathrm{pH}$ and cheesemaking traits found in this study can be explained by the positive correlations of $\mathrm{pH}$ with milk fat, protein, 
and casein in goat milk, and by the higher acidification normally observed in milk samples closer to basicity after addition of rennet, compared with those with lower pH (Dejmek and Walstra, 2004).

In cows and sheep, high milk $\mathrm{pH}$ is positively related to high SCC (Pirisi et al., 2000; Batavani et al., 2007) and correlated with lower fat and casein concentrations, as well as with reduced ratios of casein to protein (Coulon et al., 2002). In goats, the relationship between milk pH and SCS is less clear, as a high SCC is not always a symptom of bacterial infection. However, it has been evidenced that high $\mathrm{pH}$ values are commonly recorded in milk produced in early lactation $(<80$ DIM $)$ or from young goats (i.e., 1st or 2 nd parity; Vacca et al., 2018b).

\section{Effects of SCS}

Goat milk SCS affected almost all the \%REC traits (protein and solids at $P<0.001$, and energy at $P<$ $0.05)$, the $3 \% \mathrm{CY}$ traits at $P<0.001$, and $\mathrm{dCY}_{\text {SoLIDS }}$ at $P<0.01$ (Table 1). In particular, higher values of SCS were associated with a tendency toward a lower \% REC $\mathrm{R}_{\text {Protein }}$ and higher $\% \mathrm{REC}_{\text {SOLIDS }}$ (Table 4 ). The latter result was probably related to the increased water retained $\left(\% \mathrm{CY}_{\text {WATER }}\right)$ and greater amount of lactose recovered in the curd. Because $\% \mathrm{CY}_{\text {SOLIDS }}$ and $\% \mathrm{CY}_{\text {WATER }}$ increased with higher numbers of somatic cells in milk, \% $\mathrm{CY}_{\mathrm{CURD}}$ produced from high-SCS samples was higher than those derived from milk with a lower SCC. Goat milk is normally characterized by a relatively high SCC, and milk samples with high SCS frequently contain a higher percentage of protein and casein than do those with low SCS (Barrón-Bravo et al., 2013). Moreover, the relationship between goat SCC and milk fat is still controversial: some authors have reported negative (Barrón-Bravo et al., 2013; Hanuš et al., 2017) and others positive relationship (Park and Humphrey, 1986; Ying et al., 2002), whereas Min et al. (2007) did not find any relationship. A previous study evidenced that in healthy goats, milk with high SCS is characterized by high fat, protein, and casein contents, slow coagulation time, and high rate of curd-firming (Stocco et al., 2019). The positive relationships between SCS and milk composition (Pazzola et al., 2019) could explain the higher \% REC $\mathrm{ROLIDS}_{\text {s }}$ obtained from milk samples with high SCS, whereas the negative re-

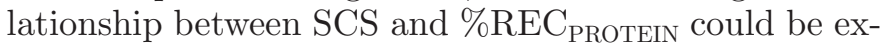
plained by the remarkable proteolytic activity of some enzymes contained in somatic cells (i.e., cathepsins, plasmin; Kelly and McSweeney, 2003), as well as by the increased proportion of whey proteins. The increase of whey proteins in milk as a result of subclinical mastitis is caused by augmented proportions of blood protein 
GOAT MILK UDDER HEALTH TRAITS AND CHEESE-MAKING
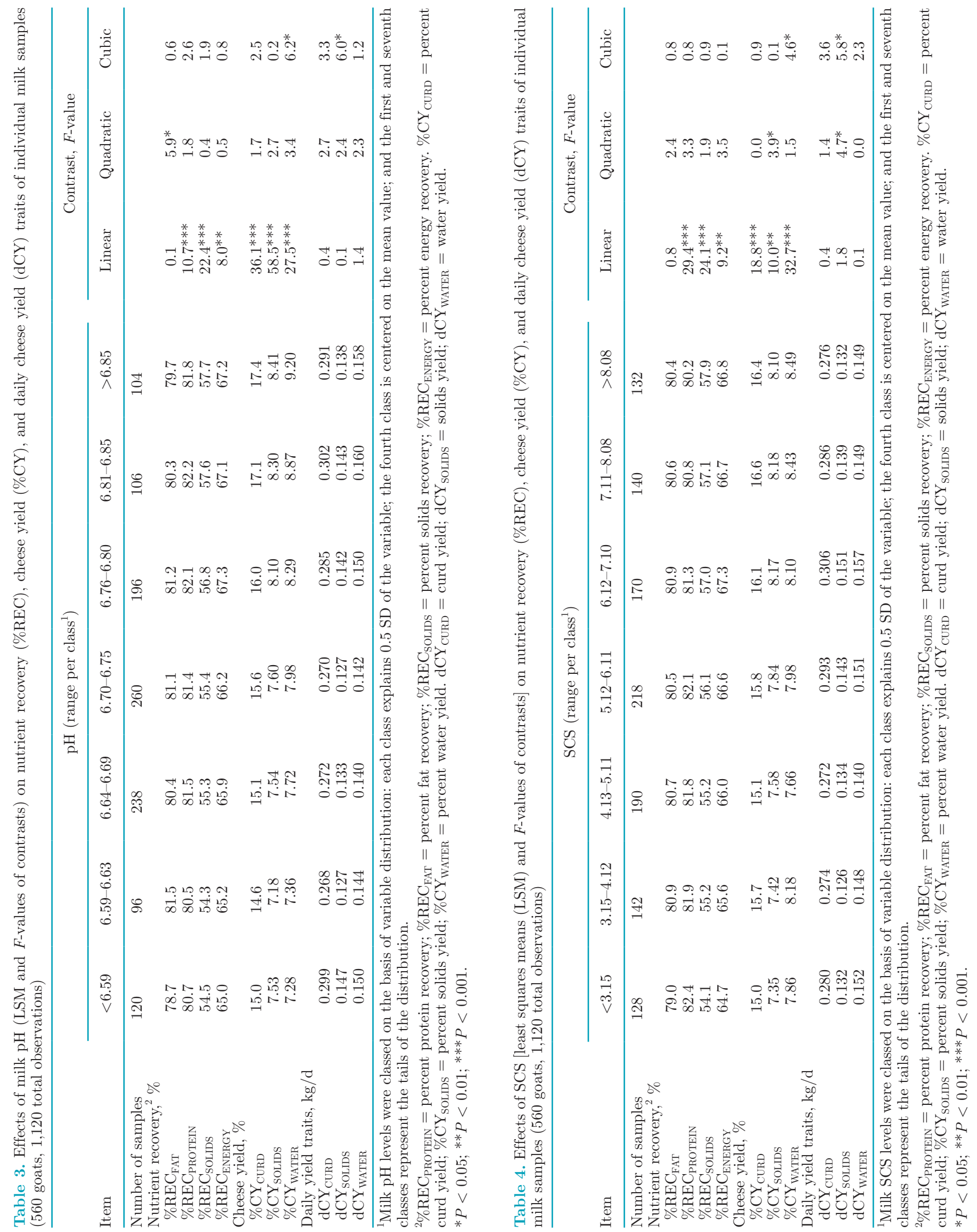
(i.e., albumin and immunoglobulins) and lactoferrin in the total protein content (Urech et al., 1999).

The positive relationship between SCS and \%CY found in this study contrasts with the results of Leitner et al. (2004), who tested the effect of subclinical mastitis on goat milk used for cheese-making, but agrees with results obtained for sheep milk (Othmane et al., 2002). However, the majority of studies on goat milk do not find any effect of SCC on \%CY. For example, in a study on the effects of 3 levels of goat milk SCC on cheese-making, Chen et al. (2010) observed no significant difference, either in \% CY or in fat and protein recovery, among semi-soft cheeses. Rather, those authors report that, after ripening, total sensory and texture scores for cheeses made from milk with high SCC are lower than those made from milk with low and medium SCC. Galina et al. (1996) report no significant correlation between \%CY and SCC for goat milk, with SCC ranging from 250,000 to more than 1,000,000 cells $/ \mathrm{mL}$. The same results were observed in comparisons of bulk milk with \%CY obtained from 2 levels of milk SCC $(<700,000$ and $>1,800,000$ cells/mL; Morgan and Gaspard, 1999). Sánchez-Macías et al. (2013) concluded that SCC has a major effect on ripening, especially on lipolysis activity (i.e., increasing free fatty acids) and on casein proteolysis. Certainly, our results were very different from those reported for individual milk samples of dairy cows, in which high milk SCC is associated with evident and nonlinear decreases of \%REC and \% CY traits (Bobbo et al., 2016).

\section{Effects of $\angle B C$}

Total bacterial count is commonly used to monitor the hygiene of dairy goat flocks and the quality of milk used to produce cheese (Pirisi et al., 2007). In this study, compared with the other indirect indicators of udder health, LBC showed the least important effect on \% REC and \% CY traits. We observed a tendency for fat to be better recovered in curds made from milk characterized by high LBC at $P<0.05$, whereas the opposite was observed for protein recovery at $P<$ 0.01 (Table 5). A previous study indicated that milk samples characterized by high LBC are associated with increased levels of fat and protein in milk and a significant decrease in curd firmness traits (Stocco et al., 2019). The findings reported in the present study for the effects of LBC evidenced a decrease of daily CY traits, at $P<0.01$ for curd and solids, and at $P$ $<0.05$ for water (Table 5). Given that dCY traits are calculated on the basis of daily milk yield of goats, this result is explained by the negative correlation between $\mathrm{dMY}$ and LBC. Indeed, a linear decrease of dMY from 2.08 to $1.63 \mathrm{~kg} / \mathrm{d}$ was observed across classes of LBC,

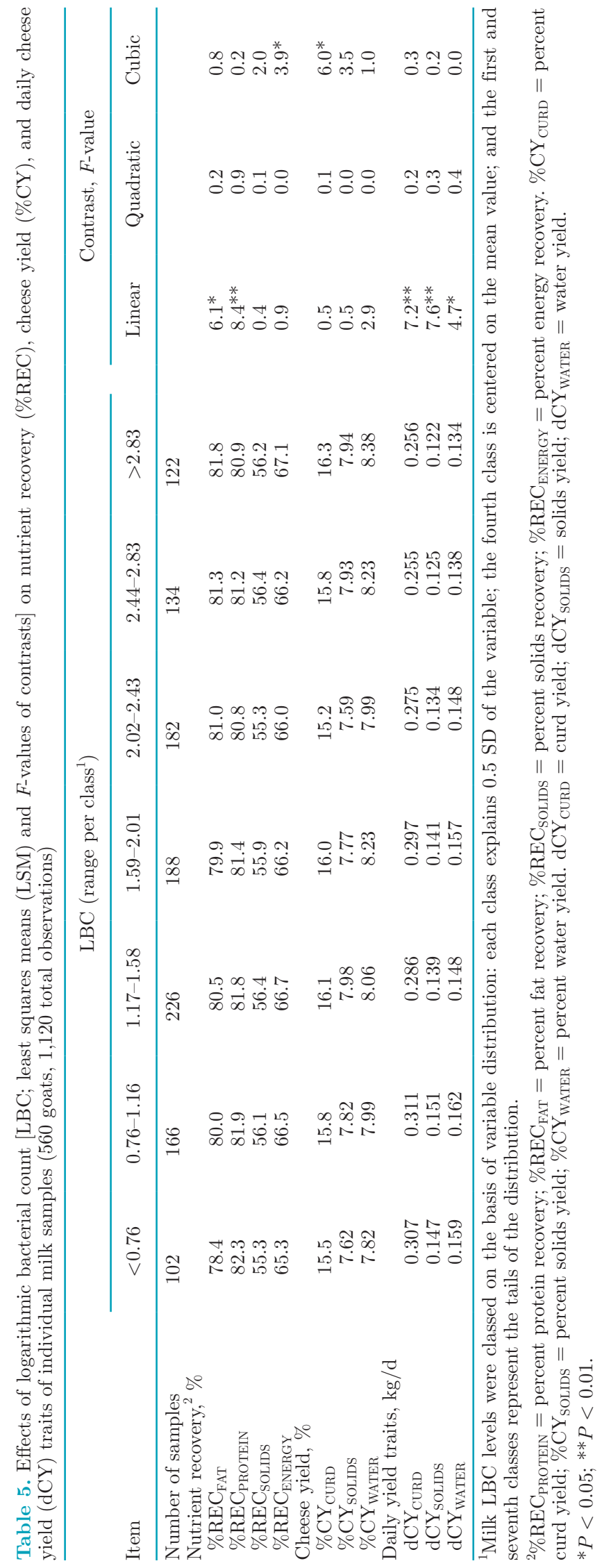

Journal of Dairy Science Vol. 102 No. 10, 2019 
correlating with losses of 50, 20, and $30 \mathrm{~g}$ per d, respectively, for $\% \mathrm{CY}_{\mathrm{CURD}}, \% \mathrm{CY}_{\mathrm{SOLIDS}}$, and $\% \mathrm{CY}_{\text {WATER }}$ (data not shown).

Previous studies of milk TBC among healthy vs. infected goats indicate that infection status causes worsening of milk quality and decreases in $\mathrm{dMY}$ and \%CY (Leitner et al., 2004). Some studies have associated IMI with decreases in milk yield (Leitner et al., 2004; Gelasakis et al., 2016), although other authors report no significant differences between infected and uninfected goats (Moroni et al., 2005; Min et al., 2007). When the association between pathogen-specific cases of subclinical mastitis and cheese-making traits in dairy cows were tested (Bobbo et al., 2017), IMI status did not affect $\% \mathrm{CY}$ traits, but only \% $\mathrm{REC}_{\mathrm{FAT}}$ and $\% \mathrm{REC}_{\text {PRoteIN. }}$ Besides the differences among species, the absence of the specific composition of the microflora in milk samples used in the present study did not allow clear attribution of the effects of different bacterial species on each cheese-making trait. However, it was clear that a high LBC in goat milk was detrimental to daily yields of both milk and cheese.

\section{Effects of $\mathrm{NaCl}$}

Both composition and mineral balance of milk are affected by $\mathrm{NaCl}$ content, as salt levels are responsible for the osmotic pressure of milk (Huppertz and Fox, 2006). The physical (e.g., texture, protein solubility) and organoleptic (e.g., flavor) traits of cheese are also affected by levels of $\mathrm{NaCl}$ (Fox et al., 2000). Despite some studies reporting on the effects of $\mathrm{NaCl}$ on the quality and coagulation properties of bovine milk (Sbodio et al., 2006; Awad, 2007), none have investigated the effects on cheese-making traits of different concentrations of $\mathrm{NaCl}$ in goat milk.

In the present study, milk samples with high $\mathrm{NaCl}$ concentration were characterized by significant decreases of both $\% \mathrm{REC}_{\mathrm{FAT}}$, at $P<0.001$, and $\% \mathrm{REC}_{\mathrm{PROTEIN}}$, at $P<0.05$, and, as a consequence, lower values for recovery of total solids and energy in the curd (Table 6 ). These findings could be explained by the osmotic properties of $\mathrm{NaCl}$ in milk. When concentration of milk $\mathrm{NaCl}$ increases, other milk components (fat, proteins, minerals) decrease, and significant physicochemical modifications occur at the casein-structure level (Huppertz and Fox, 2006). In the present study, reduced $\% \mathrm{CY}_{\mathrm{CURD}}$ was mainly attributable to a decrease in $\% \mathrm{CY}_{\text {SOLIDS }}$, and not in $\% \mathrm{CY}_{\text {WATER }}$, which seemed not to be influenced by milk $\mathrm{NaCl}$ levels. These results are in agreement with previous findings about the effects of milk $\mathrm{NaCl}$ on coagulation, curd-firming, and syneresis of cow (Sbodio et al., 2006; Awad, 2007) and goat milk (Stocco et al., 2019), evincing that higher $\mathrm{NaCl}$ concen-

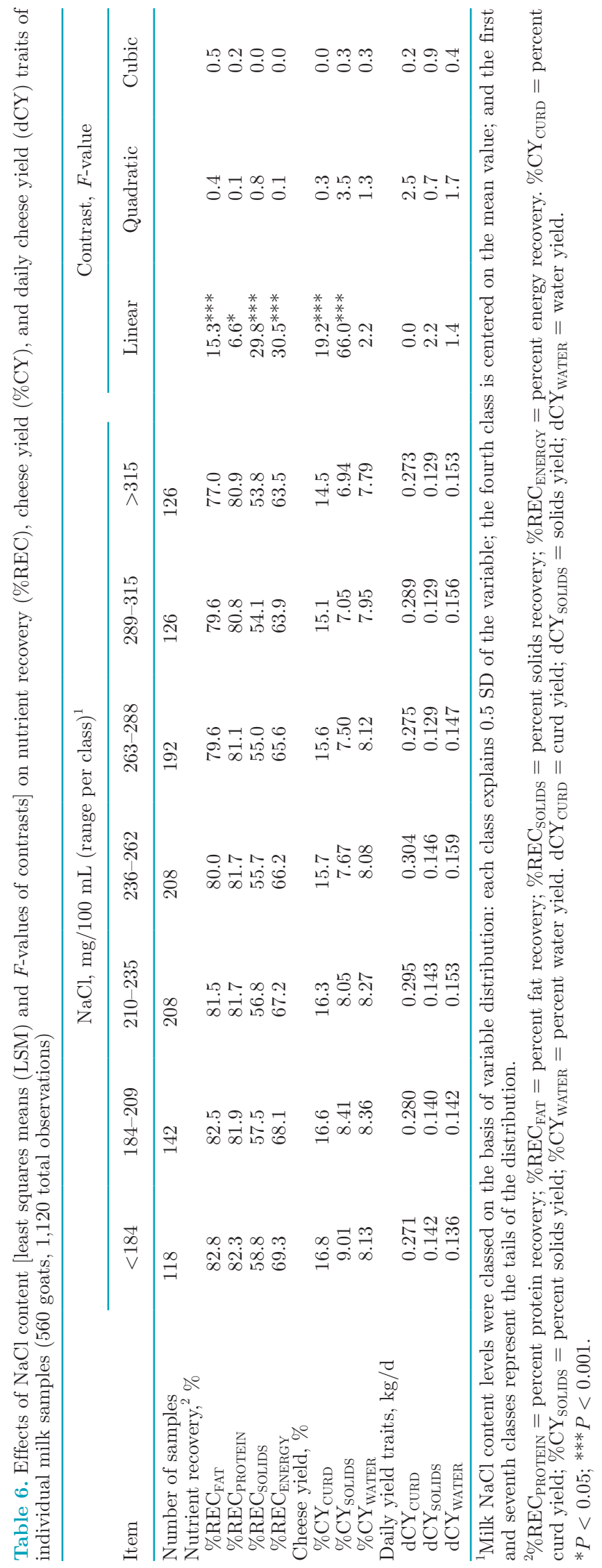

Journal of Dairy Science Vol. 102 No. 10, 2019 
trations are associated with longer curd-firming time, lower curd firmness, and lower levels of syneresis.

\section{CONCLUSIONS}

Results of this study will improve knowledge about the effects of indirect udder health indicators in milk on the recovery of nutrients in the curd, cheese yield traits, and daily cheese yields of goats. High values of milk lactose were associated with decreased nutrients recovery and reduced \% $\mathrm{CY}_{\text {SOLIDS }}$. This finding could be attributable to the reduced fat and protein contents of milk samples rich in lactose. Unlike bovine milk, goat milk samples characterized by high values of $\mathrm{pH}$ were associated with higher recovery of nutrients in the curd and higher cheese yield traits. Also contrary to results of bovine studies, high SCS in goat milk was associated with greater recovery of solids and energy in the curd. This finding may be attributable to the greater recovery of lactose in the curd and the positive correlations between SCS and milk fat, protein, and casein. Among the effects investigated in the present study, LBC was the least important factor affecting cheesemaking traits. The significant influence of $\mathrm{NaCl}$ on milk composition and coagulation explained the poorer recovery of all nutrients in the curd during cheese-making process. The significant changes in milk composition associated with increases in $\mathrm{NaCl}$ concentration probably led to lower values of cheese yield and cheese solids for milk samples characterized by high $\mathrm{NaCl}$ levels. Further studies are needed to investigate effects of indirect udder health predictors on cheese-making traits and efficiency in goat milk. As the indirect indicators in the present study exhibited high importance in the cheese-making process, such information could be used to adjust the milk-to-cheese economic value and milk payment systems.

\section{ACKNOWLEDGMENTS}

This research was supported by the Regional Government of Sardinia, Cagliari, Italy (Legge Regionale 7/2007; CUP J72I15000030007). The authors thank the participating farmers and the Sardinian Provincial Farmers Associations (Cagliari, Sassari, Nuoro, and Oristano, Italy) for giving access to flocks, the Sepi Formaggi (Marrubiu, Italy) and L'Armentizia Moderna (Guspini, Italy) for their support in sample collection, and the ARA Sardegna (Regional Farmers Association of Sardinia, Cagliari, Italy) for support in chemical milk analysis.

\section{REFERENCES}

Albenzio, M., M. Caroprese, A. Santillo, R. Marino, L. Taili, and A. Sevi. 2004. Effects of somatic cell count and stage of lactation on the plasmin activity and cheese making properties of ewe milk. J. Dairy Sci. 87:533-542.

Awad, S. 2007. Effect of sodium chloride and pH on the rennet coagulation and gel firmness. Lebensm. Wiss. Technol. 40:220-224.

Barrón-Bravo, O. G., A. J. Gutiérrez-Chávez, C. A. Ángel-Sahagún, H. H. Montaldo, L. Shepard, and M. Valencia-Posadas. 2013 Losses in milk yield, fat and protein contents according to different levels of somatic cell count in dairy goats. Small Rumin. Res. 113:421-431.

Batavani, R. A., S. Asri, and H. Naebzadeh. 2007. The effect of subclinical mastitis on milk composition in dairy cows. Iran. J. Vet. Res. 8:205-211.

Bobbo, T., C. Cipolat-Gotet, G. Bittante, and A. Cecchinato. 2016 The non-linear effect of somatic cell count on milk composition, coagulation properties, curd firmness, cheese yield and curd nutrient recovery. J. Dairy Sci. 99:5104-5119.

Bobbo, T., P. L. Ruegg, G. Stocco, E. Fiore, M. Gianesella, M. Morgante, D. Pasotto, G. Bittante, and A. Cecchinato. 2017. Associations between pathogen-specific cases of subclinical mastitis and milk yield, quality, protein composition, and cheese-making traits in dairy cows. J. Dairy Sci. 100:4868-4883.

Calvo, M. M., and E. Balcones. 2000. Some factors influencing the syneresis of bovine, ovine, and caprine milks. J. Dairy Sci. 83:17331739 .

Charjan-Ku, P. Y., N. S. Mangle, D. R. Kalorey, and S. V. Kuralkar. 2000. Changes in milk $\mathrm{pH}$ and the levels of $\mathrm{Na}$ and $\mathrm{K}$ in whey associated with udder health status of cow. Indian Vet. J. 77:1066-1068.

Chen, S. X., J. Z. Wang, J. S. Van Kessel, F. Z. Ren, and S. S. Zeng. 2010. Effect of somatic cell count in goat milk on yield, sensory quality, and fatty acid profile of semisoft cheese. J. Dairy Sci. 93:1345-1354.

Cipolat-Gotet, C., A. Cecchinato, G. Stocco, and G. Bittante. 2016. The 9-MilCA method as a rapid, partly automated protocol for simultaneously recording milk coagulation, curd firming, syneresis, cheese yield, and curd nutrients recovery or whey loss. J. Dairy Sci. 99:1065-1082.

Coulon, J.-B., P. Gasqui, J. Barnouin, A. Ollier, P. Pradel, and D. Pomiès. 2002. Effect of mastitis and related-germ on milk yield and composition during naturally-occurring udder infections in dairy cows. Anim. Res. 51:383-393.

Dejmek, P., and P. Walstra. 2004. The syneresis of rennet-coagulated curd. Pages 71-103 in Cheese Chemistry, Physics and Microbiology. Vol. 1. 3rd ed. P. F. Fox, P. L. H. McSweeney, T. M. Cogan, and T. P. Guinee, ed. Elsevier Ltd., London, UK.

Fox, P. F., T. P. Guinee, T. M. Cogan, and P. L. H. McSweeney. 2017. Fundamentals of Cheese Science. 2nd ed. Springer, New York, NY.

Fox, P. F., T. P. Guinee, T. M. Cogan, and P. L. H. McSweeney. 2000. Postcoagulation treatment of renneted milk gel. Pages 138-152 in Fundamentals of Cheese Science. 1st ed. Aspen Publishers Inc., Gaithersburg, MD.

Galina, M. A., R. Morales, B. López, and M. A. Carmona. 1996. Effect of somatic cell count on lactation and soft cheese yield by dairy goats. Small Rumin. Res. 21:251-257.

Gelasakis, A. I., A. S. Angelidis, R. Giannakou, and G. Arsenos. 2018. Bacterial subclinical mastitis and its effect on milk quality traits in low-input dairy goat herds. Vet. Rec. 183:449.

Gelasakis, A. I., A. S. Angelidis, R. Giannakou, G. Filioussis, M. S. Kalamaki, and G. Arsenos. 2016. Bacterial subclinical mastitis and its effect on milk yield in low-input dairy goat herd. J. Dairy Sci. 99:3698-3708

Guo, M., Y. W. Park, P. H. Dixon, J. A. Gilmore, and P. S. Kindstedt. 2004. Relationship between the yield of cheese (Chèvre) and chemical composition of goat milk. Small Rumin. Res. 52:103-107. 
Hanuš, O., P. Roubal, J. Kučera, M. Klimešová, R. Jedelská, and J. Kopecký. 2017. Somatic cell count and milk yield losses in goats. Acta Univ. Agric. Silvic. Mendel. Brun. 65:118.

Huppertz, T., and P. F. Fox. 2006. Effect of $\mathrm{NaCl}$ on some physicochemical properties of concentrated bovine milk. Int. Dairy J. $16: 1142-1148$.

ISO-IDF (International Organization for Standardization and International Dairy Federation). 2010. Milk and liquid milk products: Determination of total solids content. International Standard ISO 6731 and IDF 21:2010a. ISO, Geneva, Switzerland, and IDF, Brussels, Belgium.

ISO-IDF (International Organization for Standardization and International Dairy Federation). 2013. Milk and liquid milk products: Determination of fat, protein, lactose, $\mathrm{pH}$, and $\mathrm{NaCl}$ content. International Standard ISO 9622 and IDF 141:2013. ISO, Geneva, Switzerland, and IDF, Brussels, Belgium.

Kelly, A. L., and P. L. H. McSweeney. 2003. Indigenous proteolytic enzymes in milk. Pages 495-521 in Advanced Dairy Chemistry: 1. Proteins. 3rd ed. P. F. Fox, and P. L. H. McSweeney, ed. Kluwer Academic/Plenum Publishers, New York, NY.

Leitner, G., U. Merin, and N. Silanikove. 2004. Changes in milk composition as affected by subclinical mastitis in goats. J. Dairy Sci. $87: 1719-1726$.

Min, B. R., G. Tomita, and S. P. Hart. 2007. Effect of subclinical intramammary infection on somatic cell counts and chemical composition of goats' milk. J. Dairy Res. 74:204-210.

Morgan, F., and C. E. Gaspard. 1999. Influence des cellules somatiques sur les qualités technologiques du lait de chèvre et sur les caractéristiques des fromages de chèvre. Page 317 in 6èmes journées Rencontres Recherches Ruminants, Paris, France.

Moroni, P., G. Pisoni, M. Antonini, G. Ruffo, S. Carli, G. Varisco, and P. Boettcher. 2005. Subclinical mastitis and antimicrobial susceptibility of Staphylococcus caprae and Staphylococcus epidermidis isolated from two Italian goat herds. J. Dairy Sci. 88:1694-1704.

NRC (National Research Council). 2001 Nutrient Requirements of Dairy Cattle. 7th rev. ed. Natl. Acad. Press, Washington, DC.

Ogola, H., A. Shitandi, and J. Nanua. 2007. Effect of mastitis on raw milk compositional quality. J. Vet. Sci. 8:237-242.

Othmane, M. H., L. F. De La Fuente, J. A. Carriedo, and F. San Primitivo. 2002. Heritability and genetic correlations of test day milk yield and composition, individual laboratory cheese yield, and somatic cell count for dairy ewes. J. Dairy Sci. 85:2692-2698.

Park, Y. W., and R. D. Humphrey. 1986. Bacterial cell counts in goat milk and their correlations with somatic cell counts, percent fat, and protein. J. Dairy Sci. 69:32-37.

Pazzola, M., G. Stocco, M. L. Dettori, G. Bittante, and G. M. Vacca. 2019. Effect of goat milk composition on cheese-making traits and daily cheese productions. J. Dairy Sci. 102:3947-3955.

Pirisi, A., A. Lauret, and J. P. Dubeuf. 2007. Basic and incentive payments for goat and sheep milk in relation to quality. Small Rumin. Res. 68:167-178.
Pirisi, A., G. Piredda, M. Corona, M. Pes, S. Pintus, and A. Ledda. 2000. Influence of somatic cell count on ewe's milk composition, cheese yield and cheese quality. Pages 47-59 in Proc. Sixth Great Lakes Dairy Sheep Symposium, Guelph, Canada.

Pyörälä, S. 2003. Indicators of inflammation in the diagnosis of mastitis. Vet. Res. 34:565-578.

Rupp, R., B. Bergonier, S. Dion, M. C. Hygonenq, M. R. Aurel, C. Robert-Granié, and G. Foucras. 2009. Response to somatic cell count-based selection for mastitis resistance in a divergent selection experiment in sheep. J. Dairy Sci. 92:1203-1219.

Sánchez-Macías, D., A. Morales-de la Nuez, A. Torres, L. E. Hernández-Castellano, R. Jiménez-Flores, N. Castro, and A. Argüello. 2013. Effects of addition of somatic cells to caprine milk on cheese quality. Int. Dairy J. 29:61-67.

Sbodio, O. A., E. J. Tercero, R. Coutaz, and G. R. Revelli. 2006. Effect of rennet and sodium chloride concentration on milk coagulation properties. CYTA J. Food 5:182-188.

Stocco, G., C. Cipolat-Gotet, A. Cecchinato, L. Calamari, and G. Bittante. 2015. Milk skimming heating, acidification, lysozyme, and rennet affect the pattern, repeatability, and predictability of milk coagulation properties and of curd-firming model parameters: A case study of Grana Padano. J. Dairy Sci. 98:5052-5067.

Stocco, G., M. Pazzola, M. L. Dettori, C. Cipolat-Gotet, A. Summer, and G. M. Vacca. 2019. The effect of udder health indicators on composition and coagulation traits of goat milk. Int. Dairy J. In press. 10.1016/j.idairyj.2019.06.005.

Stocco, G., M. Pazzola, M. L. Dettori, P. Paschino, G. Bittante, and G. M. Vacca. 2018. Effect of composition on coagulation, curdfirming and syneresis of goat milk. J. Dairy Sci. 101:9693-9702.

Stuhr, T., and K. Aulrich. 2010. Intramammary infections in dairy goats: Recent knowledge and indicators for detection of subclinical mastitis. Agriculture and Forestry Research. 4:267-280.

Summer, A., P. Franceschi, P. Formaggioni, and M. Malacarne. 2015. Influence of milk somatic cell count on Parmigiano-Reggiano cheese yield. J. Dairy Res. 82:222-227.

Urech, E., Z. Puhan, and M. Schällibaum. 1999. Changes in milk protein fraction as affected by subclinical mastitis. J. Dairy Sci. 82:2402-2411.

Vacca, G. M., G. Stocco, M. L. Dettori, E. Pira, G. Bittante, and M. Pazzola. 2018a. Milk yield, quality and coagulation properties of six breeds of goats: Environmental and individual variability. J. Dairy Sci. 101:7236-7247.

Vacca, G. M., G. Stocco, M. L. Dettori, A. Summer, C. Cipolat-Gotet, G. Bittante, and M. Pazzola. 2018b. Cheese yield, cheese-making efficiency, and daily production of 6 breeds of goats. J. Dairy Sci. 101:7817-7832.

Ying, C., H.-T. Wang, and J.-T. Hsu. 2002. Relationship of somatic cell count, physical, chemical and enzymatic properties to the bacterial standard plate count in dairy goat milk. Livest. Prod. Sci. 74:63-77. 